\title{
Relationship among Identity, Image and Construed External Image: A Missing Link on Acquisitions
}

\author{
Patrícia Jardim da Palma ${ }^{1}$, Miguel Pereira Lopes ${ }^{1}$ \& André Escórcio Soares ${ }^{2}$ \\ ${ }^{1}$ School of Social and Political Sciences, Lisbon Tech University, Lisboa, Portugal \\ 2 School of Management, Polytechnic Institute of Tomar, Tomar, Portugal \\ Correspondence: Patrícia Jardim da Palma, School of Social and Political Sciences, Lisbon Tech University, Rua \\ Almerindo Lessa, 1300-663 Lisboa, Portugal. Tel: 351-21-361-9430. E-mail: ppalma@iscsp.utl.pt
}

Received: August 6, 2012

Accepted: August 24, 2012

Online Published: September 3, 2012

doi:10.5539/ibr.v5n10p115

URL: http://dx.doi.org/10.5539/ibr.v5n10p115

\begin{abstract}
We tested the effect of the relationship among the identity, image and construed external image of both the acquiring and the acquired companies on intergroup relations, during the post-acquisition phase. The case study of a post-acquisition insurance company showed that the identity was not consistent with the construed external image either for the acquiring or the acquired companies. Consistency between identity and image was found only for the acquiring firm. Our study evidenced that the identity, image and construed external image altogether contribute to a better understanding of intergroup relations than do any of these variables per se. Changes in this relationship should thus be taken into account to improve the organizational performance.
\end{abstract}

Keywords: construed external image, image, identity, acquisition, intergroup relations

\section{Introduction}

In recent years, mergers and acquisitions have been used as strategic tools by companies all over the world. Several reasons, such as growth, synergy and expansion strategies (Andrade, Mitchell \& Stafford, 2001; Eschen \& Bresser, 2005; Gaughan, 2001) explain this rising popularity. Despite their major importance, mergers and acquisitions have not proved reliable in achieving the purpose they were designed for. It is estimated that about 50-80 percent of mergers and acquisitions have failed to meet their financial goals (Cornett-DeVito \& Friedman, 1995). Several studies have shown that satisfaction and commitment of employees decrease after a merger or acquisition (Newman \& Krzystofiak, 1993). The understanding of why mergers and acquisitions fail has stimulated the work of authors in many different fields, from economics and finance to organizational behavior.

In an effort to understand the conditions that favor the success of an acquisition, several authors has established that it depends on the similarities and complementarities that exist between the acquiring and the acquired companies (Finkelstein \& Haleblian, 2002). Those similarities facilitate interaction and coordination between the different organizational members, thus improving the post-acquisition integration (Larson \& Finkelstein, 1999; Graebner \& Eisenhardt, 2004). For instance, several studies (e.g. Elsass \& Veiga, 1994; Nahavandi \& Malekzadeh, 1988) have demonstrated that cultural differences are responsible for problems in communication, learning and knowledge transfer between both companies during the integration process. Such problems of interaction can better be solved by understanding the cognitive and social processes that take place during organizational integration and that influence how groups perceive themselves and each other.

In order to explain those processes, researchers have relied on the differences in the identity of the acquiring and the acquired companies (how individuals perceive their own company), considering that individuals favor interactions with those who are similar and share the same identity (e.g. Salk \& Shenkar, 2001; Terry \& Callan, 1998; Terry \& O'Brien, 2001). On the other hand, the literature on group relations has highlighted the importance of image in intergroup contexts (how members from different companies perceive each other), emphasizing that individuals prefer to interact with those that perceive them in a way that is congruent with their own self-views (Swann, 1987; Swann, Stein-Seroussi \& Giesler, 1992). Other scholars have also highlighted the role of construed external image (CEI) (how members of a company think others perceive them) as a key determinant of behavior (e.g. Dutton, Dukerich \& Harquail, 1994; Gioia, Schultz \& Corley, 2000). Given that in addition to identity, both image and CEI explain how different actors interact and conflict with each other, 
perhaps the relationship among these perceptions is even more important than considering them apart.

We seek to advance these lines of research by showing that identity, image and CEI altogether contributes to a better understanding of group dynamics following an acquisition. To do so, we used data from a consultancy project on an acquisition that intended to improve the quality of the relationships between the acquiring and the acquired companies on the post-acquisition phase. To the best of our knowledge there is no significant research about the importance of the consistency among organizational identity, image and CEI in understanding intergroup interaction. Thus, the purpose of our case study is to test the effect of relationship among the identity, image and construed external image of both acquiring and acquired companies on intergroup relations, during the pos-acquisition phase. Although the literature on this topic has already focused on differences in organizational identity, emphasizing both conflict and power distances, it has not devoted much attention to image and CEI or their impact.

In this sense, the study contributes to the literature on mergers and acquisitions as well as to intergroup relations literature in four ways. First, our study shows that more important than considering identity, image and CEI separately, it is the relationship among each other that may be regarded as a major source of success or failure of mergers and acquisitions. We found that even in the presence of consistency between identity and image, when consistency between identity and CEI does not exist, members from different companies feel apprehensive about each other, which can undermine their interactions. The relationship among those processes should thus be taken into account in order to improve the organizational performance. Second, this study reveals that the relationship between organizational identity and image is affected by the status of the organization. Researchers have emphasized how important it is to attain consistency between identity and image, but the conditions influencing this relationship have not been yet addressed. Third, we highlight a construct that has received little attention in the field of mergers and acquisitions and in the organizational sciences: CEI. As such, we introduce some systematization in the field of identity by showing empirically that image and CEI are two distinctive constructs, as they should not be used as equivalent. Fourth, by finding that members from the acquiring company like those from the acquired company also feel apprehensive about each other, we relaunch the debate on the strong-weak partner dichotomy that exists in the literature on mergers and acquisitions.

The paper is organized as follows: we first review how differences on identity have been used to understand the behavior of the members from both the acquiring and the acquired companies during the post-acquisition phase. We next show how image and CEI are important concepts to explain cohesion and cooperation between the members of both companies, and introduce our five hypotheses. Then we describe how the study was conducted, show the results and discuss them in relation to the hypotheses. We finish by outlining the main conclusions, implications and limitations of our research.

\section{The Current Study}

\subsection{The Role of Identity, Image and CEI in the Post-acquisition Phase}

To understand cognitive and social processes in the post-acquisition phase, previous research has centered on organizational identity, which may be defined as the shared understanding of the central, distinctive and enduring properties of an organization by its members (Albert \& Whetten, 1985). Organizational identity can also be conceptualized as the "ongoing efforts to answer the question "who are we?" and - by implication "How should we act?” (Alvesson, Ashcraft \& Thomas, 2008; Desrochers \& Sargent, 2004).

The definition of organizational image is not as consensual in the organizational literature as that of organizational identity. As the notion of organizational image has been used in a diversity of fields, such as organizational behavior or marketing (Dutton, Dukerich \& Harquail, 1994), different terms have been proposed to express the same idea (e.g. corporate image or reputation). Organizational image has often been used as an equivalent of CEI (e.g Dutton \& Dukerich, 1991; Hatch \& Schultz, 1997, 2002). In this paper we rely on the definition of Alvesson (2001) and Berg (1985), which conceptualizes organizational image as how outside members perceive the organization. For the concept of CEI, we consider the definition of Dutton, Dukerich and Harquail (1994) and Labianca, Fairbank, Thomas, Gioia and Umphress (2001): how do insiders think outsiders perceive their organization.

In the organizational context, several authors have highlighted the importance of identity and image for the organizational performance, motivation and cooperation among organizational actors (e.g. Dutton \& Dukerich, 1991; Dutton, Dukerich \& Harquail, 1994; Mael \& Ashforth, 1992) and securing loyalty from external costumers (e.g. Melawar, Hussey \& Srivoravilai, 2005). Organizational image also influences intergroup relations, as defended by the self-consistency theories (e.g. Festinger, 1957; Swann, 1987). These theories suggest that individuals seek interaction with those that have an image that is consistent with their self-views, 
regardless of whether these self-views are positive or negative (e.g. Swann, Hixon, Stein-Seroussi \& Gilbert, 1990; Swann, Pelham \& Krull, 1989). According to such a framework, people search for consistency between identity and image, in order to reduce or to avoid cognitive dissonance and to maintain perceptions of predictability and control (Swann, Stein-Seroussi \& Giesler, 1992).

Earlier research has shown that consistency between identity and image is a desirable condition in the organizational context, promoting high levels of trust, cooperation and coordination among organizational members (e.g. Larsson, Brousseau, Driver, Holmqvist \& Tarnovskaya, 2003; Milton \& Westphal, 2005). CEI has not received the same level of attention in the literature. Researchers have only theoretically postulated that it should be important to minimize discrepancies between identity and CEI (Dutton \& Dukerich, 1991; Gioia, Schultz \& Corley, 2000; Gioia \& Thomas, 1996).

Mergers and acquisitions are likely to make employees' pre-merger group membership salient, a condition that is sufficient to produce intergroup competition (Brewer, 1979; Kramer, 1991). So, differences on the identity, image and CEI of the acquiring and acquired companies can be better understood within the social identity framework. Social identity theory considers that, as an individual categorizes himself as a member of a social group, similarities among ingroup members are reinforced, while differences between ingroup and outgroup are emphasized (Tajfel, 1982). Because people strive to attain a positive identity in order to maintain a positive self-esteem (Tajfel \& Turner, 1979; Tajfel \& Turner, 1986), individuals favor their ingroup to achieve positive distinctiveness in comparison with relevant outgroups.

Those patterns of intergroup relations may harm post-acquisition integration success. Perceptions of "us" versus "them" may persist long after the acquisition process, creating serious obstacles to the construction of a common identity (e.g. Seo \& Hill, 2005; Vaara, Tienari \& Säntti, 2003). As identity is socially constructed, i.e. it is constantly developing through interaction with others (e.g. Desrochers \& Sargent, 2004; Parker, 2000; Ybema, Keenoy, Oswick, Beverungen, Ellis \& Sabelis, 2009), the formation of a common identity in the new organization is expected after an acquisition. Otherwise, social cohesion and interaction and, ultimately, effective functioning of the post-acquisition organization may be undermined. Building a common identity after an acquisition, however, is a hard task, as the groups involved do not relinquish their old identities (e.g. Empson, 2004; Salk \& Shenkar, 2001).

Given the above discussion, although the relationship among identity, image and CEI has a positive impact on intergroup behavior, it has been studied neither in the field of mergers and acquisitions, nor in that of organizational change in general.

\subsection{Identity, Image and CEI of the Acquiring Company}

Given that the acquiring company is more powerful than the acquired one (Rentsch \& Schneider, 1991), the identity of the post-acquisition company tends to remain quite the same as that of the acquiring company. As a result, members from the acquiring company are more likely to perceive a sense of continuity between the old and the new organization (Knippenberg, Knippenberg, Monden \& Lima, 2002), leading them to act as if the post-acquisition company remains "their organization" (e.g. Risberg, 1999). Members from the acquiring company do not have to change their behavior between the pre and the post-acquisition phase, in order to adapt to a different organization. Because their behavior is not supposed to change, as the acquiring company is the higher-status group, organizational members perceive a positive distinctiveness in comparison to the acquired company (Tajfel, 1982).

Consequently, this group perceives a positive identity, which promotes a positive self-esteem (Tajfel \& Turner, 1979; Tajfel \& Turner, 1986). As these differences in group status are recognized by both companies (e.g. Terry \& Callan, 1998; Terry \& O’Brien, 2001), members from the acquiring company are regarded by members of the acquired company in a positive way, in congruence with their own self-views. We can thus hypothesize consistency between how members from the acquiring company define themselves and how they are seen by the members from the acquired company.

As mentioned above, the concept of CEI has not received so much attention in the organizational literature. Based on identity-image consistency, on the one hand, and on status-differences, on the other, we postulate that members from the acquiring company will expect congruence between how they define themselves and how they think others (from the acquired company) define them. Because members from the acquiring company are the higher-status group, and they believe that this position is acknowledged by the lower-status group, members from the acquiring company expect to be perceived in a positive way, in line with how they view themselves. As such, an identity-CEI consistency is expected. Concerning the above, we thus propose that: 
H1: There is a consistency between organizational identity and image for members from the acquiring company during the post-acquisition phase.

H2: There is a consistency between organizational identity and CEI for members from the acquiring company during the post-acquisition phase.

\subsection{Identity, Image and CEI of the Acquired Company}

The acquired company may be in a low-status position, as the acquiring organization tends to be richer or powerful (Rentsch \& Schneider, 1991), but their members strive to maintain a positive identity (Tajfel \& Turner, 1986). So, when their relative low-status becomes salient, members from the acquired organization will show high-levels of ingroup bias on irrelevant dimensions to restore positivity (e.g. Elsbach \& Kramer, 1996; Turner \& Tajfel, 1979). Although the evaluation of irrelevant dimensions of members from the acquired organization may get better, perceptions regarding the relevant dimensions remain quite the same. As such, taking into account that both companies acknowledge status differences between both groups (e.g. Terry \& Callan, 1998; Terry \& O'Brien, 2001), members from the acquiring company evaluate their partners in a more negative light than they view themselves. Low-status members expect, however, those negative evaluations, because they recognize the status differences that exist between both companies. As such, we do not predict consistency between identity and image nor between identity and CEI with regard to members of the acquired company. We can thus postulate that:

H3: Organizational identity is perceived as more positive than organizational image for the members from the acquired company during the post-acquisition phase.

H4: Organizational identity is perceived as more positive than CEI for the members from the acquired company during the post-acquisition phase.

Relations among Identity, Image and CEI in the Post-acquisition Phase

Given that not only identity but also image and CEI have a positive impact on how organizational members interact and communicate (e.g. Elsbach \& Kramer, 1996; Turner \& Tajfel, 1979), we want to explore if these perceptions considered together produce a better evaluation of the integration between the acquiring and the acquired members, than a consideration of these variables independently. As such we postulate:

H5: Organizational identity, image and CEI altogether have a more significant impact on the evaluation of intergroup relations that any of them alone.

\section{Method}

We used the case study approach because we were interested in understanding how the acquiring and acquired firms perceive each other and how these perceptions affected the evaluation of the intergroup relations. Therefore, our study is part of a major acquisition intervention project, which intended to improve the quality of the relationships between members of the acquiring and the acquired companies. As suggested by Yin (1986), the case study methodology is used to explore the real-life context in which an intervention has occurred, via multiple sources of evidence. This methodology is focused on a complex issue or object, so that it is used to strengthen what is already known through previous research. Case studies highlight detailed contextual analysis of specific events or conditions, in order to capture their relationships (Creswell, 2003). As such, we relied on this methodology to get a detailed comprehension of the dynamics among the identity, image and CEI during an acquisition, which processes are not always easy to examine in real-time.

The acquiring company (labeled here as PICKER) acquired APPLE (the pseudonym for the acquired company) with two main purposes: 1) a reinforcement of customer base and 2) an increase in the portfolio services, in order to facilitate cross-selling. As the acquisition took place, employees from APPLE were incorporated in PICKER headquarters. The process did not produce immediate job losses. There was, however, a readjustment in the day-to-day organizational functioning of APPLE, as it came under the control of PICKER.

\subsection{The Partners: A Brief Characterization}

PICKER was part of one of the most prestigious and respectable groups in the German insurance sector. Before the acquisition, the acquiring company dealt mainly with life and health insurance, and had a total of 232 employees. It could be described as having high quality and strong customer orientation. APPLE also belonged to a prestigious group in the British insurance sector. The focus of APPLE was mainly on automobile insurance. Before the acquisition, the acquired company was a relatively small enterprise, with 52 workers. At the time $A P P L E$ was acquired, it was a profitable organization. 
This study began three months after the acquisition. By this time, members from PICKER and APPLE did not interact with each other, even during lunch time. Data were collected in the post-acquisition company over a period of four months. As the construction of a new identity takes several months or even years (Dutton, Dukerich \& Harquail, 1994; Gioia \& Thomas, 1996), members from PICKER and APPLE tended to remain as two different groups during the initial months of the post-acquisition phase. During this time, the acquisition should have allowed members from both companies to develop perceptions of each other, as they interacted and worked together.

\subsection{Design and Data Collection}

We used a mixed design to study a post-acquisition insurance organization with two sequential steps: a qualitative followed by a quantitative phase. The purposes of the qualitative phase were: (1) to analyze what the acquisition situation meant during the post-acquisition phase and (2) to identify the key-indicators of identity, image and CEI of the post-acquisition organizational members. Data was collected from a qualitative questionnaire that took about 20 minutes to fill. These data were later used to build a quantitative questionnaire that was first tested on a small pilot study, to check the external validity of the items. The quantitative questionnaire aimed to compare identity, image and CEI of organizational members that came from the acquiring and the acquired organization. The quantitative questionnaire took about 30 minutes to be completed.

\subsection{Participants}

There were 20 participants in the qualitative phase, 10 from each company. In the quantitative phase, a total of 195 questionnaires were returned, corresponding to a response rate of approximately 80 percent. This sample included approximately the same proportion of employees from the two pre-acquisition organizations. Specifically, this sample integrated 160 employees from PICKER and 35 from APPLE, each one representing about 70 percent of all the employees from each company (PICKER had a total of 232 employees and APPLE 52). They were all full-time insurance consultants, with responsibilities for managing a number of client accounts.

\subsection{Measures and Data Analysis}

Qualitative Questionnaire. Two versions of the same qualitative questionnaire were developed: The PICKER Qualitative Questionnaire, to be filled by the acquiring members and the APPLE Qualitative Questionnaire, to be applied to the acquired members. Each questionnaire is composed by 4 questions (table 1 ).

Table 1. Questions explored in the Qualitative phase applied to PICKER

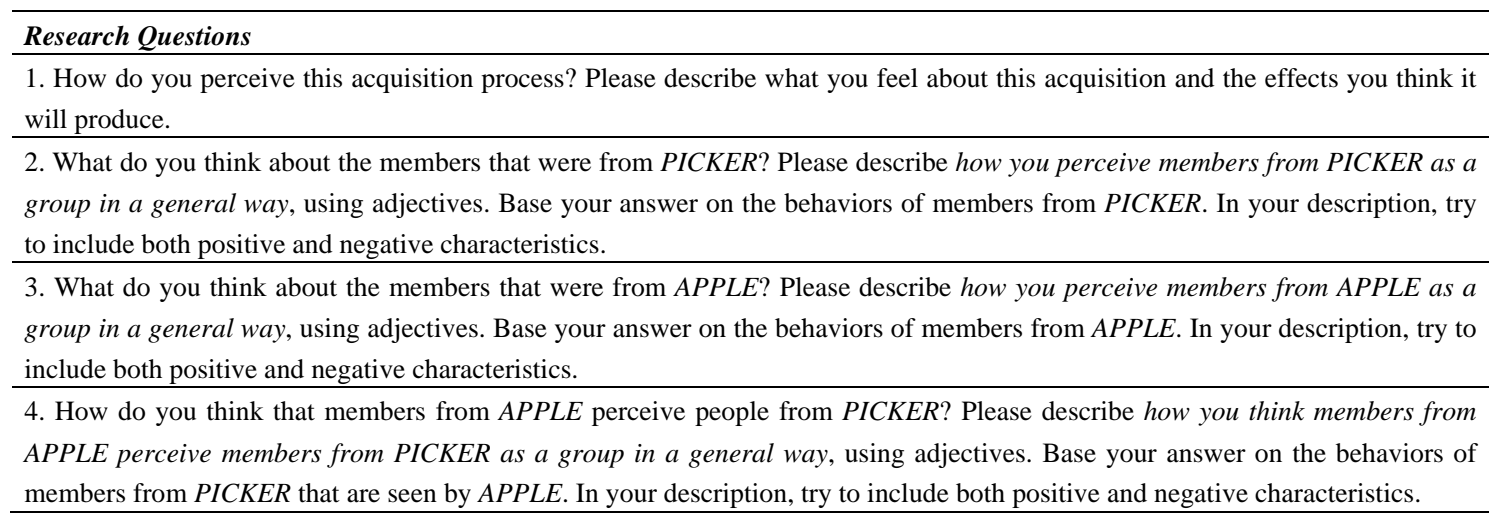

The first question was targeted to how both groups evaluated the acquisition and the effects it produced in the organizational life. This question was included to let both the acquiring and the acquired members express what they felt about post-acquisition integration and how they interacted with each other.

The second question focused on how members from each company perceived themselves as a group (as the acquiring, in the case of PICKER, or the acquired group, in the case of APPLE). It was based on the question defining organizational identity: "who are we?” (Albert \& Whetten, 1985; Ashforth \& Mael, 1989). We asked respondents to describe themselves using adjectives, as proposed by Bartel (2001). An open-question was made in order to elicit a wide variety of responses, a method similar to "free association", as recommended by Pratt and Rafaeli (1997). To measure organizational identity we relied on how respondents defined their colleagues from the pre-acquisition company as a group. So, the evaluation of identity was based on the characteristics of the individuals that form the organization and not on the characteristics of the organization as a whole. Although 
both measures are reported in the literature, we followed the suggestions of Albert and Whetten (1985) and Foreman and Whetten (2002).

The third question measured how organizational members from each company saw members from the other company and was anchored in the question representing organizational image: "How do others perceive us?" (Alvesson, 2001; Berg, 1985). Although the concept of image refers to the totality of outsiders' perceptions of the firm, in this study we limited these perceptions to members of the counterpart company only (the acquired company in the case of the acquiring one, and the acquiring company in the case of the acquired one).

The fourth question was derived from the central question in the CEI literature: "How do we think outsiders perceive us?” (Dutton, Dukerich \& Harquail, 1994; Gioia, Schultz \& Corley, 2000). It evaluated how people from each company believe that the members from the other company perceive them. As with the concept of image, in the case of CEI the term "outsiders" refers to members of the counterpart company only.

In the case of the second, third and fourth questions, respondents were asked to base their answers on the behaviors of the group they were describing. This instruction aimed at maximizing the probability of anchoring descriptions of members from the group on behaviors that were actually seen rather than on stereotypes formed about the groups, and was the rationale for beginning the study only three months after the acquisition.

Following Miles and Huberman (1994), answers to the four questions were analyzed one by one. Data were fractured and examined line by line (Strauss \& Corbin, 1998). Units of meaning were coded, generating a pool of first-level terms and concepts. Next, through a process of constant comparison, in which similarities and differences were identified, first-level codes were grouped into a smaller number of categories, second-level terms, that defined similar ideas. Analysis of the first question generated a total of 23 categories, or second-level terms, which were used as possible indicators of the consequences of the acquisition that were perceived by the organizational members. These same codes were used as items of the quantitative questionnaire (see Table 2). From responses to the last three questions (organizational identity, organizational image and CEI) a set of 28 second-level terms emerged. They were used as possible indicators of organizational members' perceptions of organizational identity, image and CEI. These same codes were used as items of the quantitative questionnaire (Table 3).

Table 2. Items, means and standard deviations of the scale "Evaluation of the Acquisition"

\begin{tabular}{|c|c|c|c|c|c|c|}
\hline \multirow{2}{*}{$\begin{array}{l}\text { Acquisition's Consequences } \\
\text { Item }\end{array}$} & \multicolumn{2}{|c|}{ PICKER \& APPLE } & \multicolumn{2}{|c|}{ PICKER } & \multicolumn{2}{|c|}{ APPLE } \\
\hline & Mean & S.D. & Mean & S.D. & Mean & S.D. \\
\hline \multicolumn{7}{|l|}{ At this moment, I think that the acquisition means ... } \\
\hline 1. An opportunity and a challenge in personal and professional terms. & 4.47 & 1.43 & 4.44 & 1.40 & 4.62 & 1.55 \\
\hline 2. A fear of not being successful in the new company and being rejected.* & 1.85 & 1.30 & 1.79 & 1.20 & 2.50 & 1.48 \\
\hline 3. Effectiveness increase in the internal operations, processes and procedures. & 3.43 & 1.37 & 3.39 & 1.37 & 3.65 & 1.34 \\
\hline 4. Losing identity as a consequence of entering in a new company.* & 2.65 & 1.55 & 2.51 & 1.51 & 3.31 & 1.60 \\
\hline 5. Learning new knowledge. & 4.68 & 1.40 & 4.64 & 1.38 & 4.82 & 1.46 \\
\hline 6. An ineffective growth strategy.* & 1.82 & 1.23 & 1.84 & 1.23 & 1.70 & 1.27 \\
\hline 7. Having better tools to give a high quality service. & 4.64 & 1.34 & 4.58 & 1.31 & 4.88 & 1.45 \\
\hline 8. Enlarging the product portfolio with products that I don't know how to & 4.35 & 1.61 & 4.30 & 1.59 & 3.83 & 1.58 \\
\hline use.* & 5.28 & 1.01 & 5.29 & 0.99 & 5.26 & 1.09 \\
\hline 9. An opportunity to increase cross-selling and customer’s portfolio. & 4.16 & 1.52 & 4.02 & 1.51 & 4.76 & 1.44 \\
\hline 10. Benefiting from the integration in a wider company. & 2.36 & 1.42 & 2.40 & 1.40 & 2.17 & 1.50 \\
\hline $\begin{array}{l}\text { 11. A strategy to grow in the short term, but with no sustainability in the } \\
\text { future.* }\end{array}$ & 4.28 & 1.30 & 4.16 & 1.28 & 4.82 & 1.25 \\
\hline 12. An opportunity to show management skills and know-how. & 2.33 & 1.52 & 2.46 & 1.55 & 1.68 & 1.17 \\
\hline 13. A threat to the organizational culture of my company.* & 4.64 & 1.20 & 4.57 & 1.17 & 4.80 & 1.35 \\
\hline 14. A better future for my company. & 3.10 & 1.59 & 3.18 & 1.62 & 2.96 & 1.45 \\
\hline 15. Difficulties of integration in the new company.* & 5.03 & 1.01 & 5.07 & 0.96 & 4.80 & 1.21 \\
\hline 16. More competitiveness in the market. & 2.78 & 1.51 & 2.74 & 1.47 & 2.95 & 1.72 \\
\hline 17. Low trust in my new colleagues.* & 5.03 & 1.17 & 5.02 & 1.10 & 5.06 & 1.50 \\
\hline 18. Obtaining a wider set of products. & 3.57 & 1.63 & 3.55 & 1.64 & 3.71 & 1.46 \\
\hline 19. A threat to employment.* & 3.45 & 1.32 & 3.43 & 1.31 & 3.51 & 1.34 \\
\hline 20. A better relationship among colleagues. & 4.66 & 1.28 & 4.59 & 1.29 & 5.00 & 1.21 \\
\hline 21. New opportunities for the most adaptable and prepared employees. & 2.91 & 1.80 & 2.52 & 1.60 & 4.68 & 1.61 \\
\hline 22. A decrease in social benefits.* & 3.21 & 1.48 & 3.08 & 1.47 & 3.56 & 1.44 \\
\hline 23. A positive salary evolution. & & & & & & \\
\hline
\end{tabular}

Note: * Denotes a reversed item. 
Table 3. Evaluation of "Organizational Identity", "Organizational Image” and "CEI” in the Quantitative Questionnaire

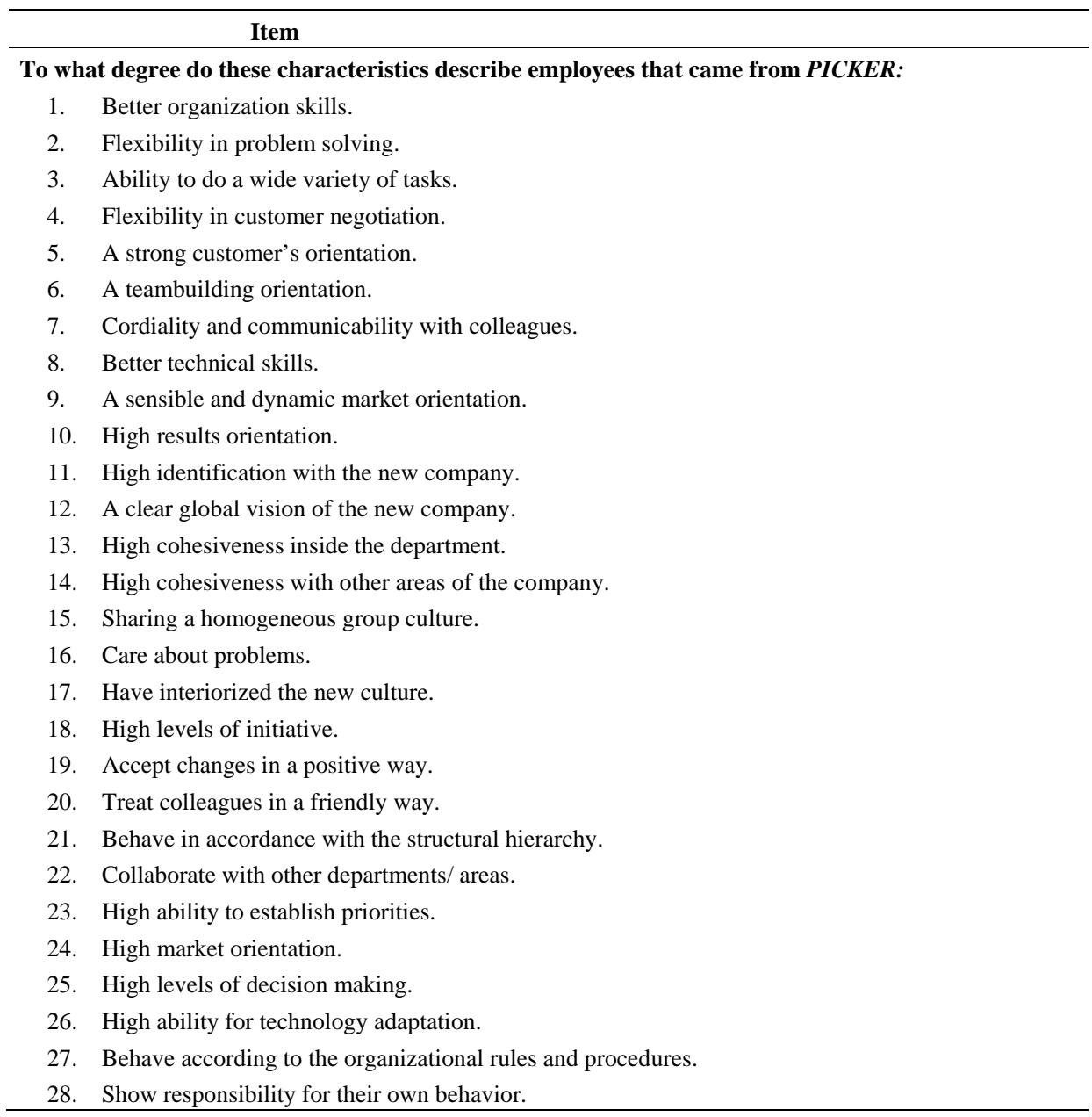

Quantitative Questionnaire. Immediately after analyzing qualitative data, we developed the quantitative questionnaire aimed to compare identity, image and CEI of organizational members that came from both organizations.

The questionnaire contained the indicators of organizational members' perceptions, as suggested by Bartel (2001) and Foreman and Whetten (2002). This measure was composed of four parts. The first part was directed at the evaluation of the acquisition in terms of the effects it had on the organizational functioning and was composed of 23 items (Table 2). The second, third and fourth parts measured organizational identity, organizational image and CEI, respectively, with 28 items each (Table 3). A 6-point scale was used, from "I strongly disagree" (1) to "I strongly agree" (6). We decided to use the same items in the second, third and fourth parts of the questionnaire because: (1) the same items were mentioned for evaluating organizational identity, image and CEI in the qualitative phase; (2) we sought to compare the answers between members from PICKER and APPLE.

\section{Results}

We present the results in two steps, beginning with a preliminary analysis to confirm that organizational identity, organizational image and CEI are independent variables. Next, we present the perceptions of both groups about each other and we finish by examining data in line with our five hypotheses.

\subsection{Preliminary Analysis}

We conducted a confirmatory factor analysis (CFA) of the items pertaining to organizational identity, organizational image and CEI in order to check for construct independence. Results indicated that a three-factor model fit the data moderately well $\left[X^{2} / d f=2.16\right.$, goodness-of-fit index $(\mathrm{GFI})=.59$, comparative fit index (CFI) $=.76$, root-mean-square error of approximation $($ RMSEA) $=.07]$. The correlation between the Organizational 
Image and Organizational Identity was suppressed of the model as demonstrated to be insignificant $(\mathrm{r}=.01$; $\mathrm{p}=.856)$. Item loadings were as proposed and were significant $(\mathrm{p}<.001)$, providing evidence for convergent validity. The hypothesis that the three variables converged on one common factor was rejected because of the poorer fit in the 1 factor model $\left[+X^{2}(3)=0,179, \mathrm{p}<.980\right]$, as the regression weights from the common factor had no significant impact on the 3 variables ( $\mathrm{P}_{\mathrm{OIM}}=.699$; $\mathrm{P}_{\mathrm{OID}}=.703$; $\mathrm{p}_{\mathrm{CEI}}=.603$ ).

In conclusion, we considered our three variables - organizational identity, organizational image and CEI - to be not only theoretically, but also empirically distinguishable, with an evidence of discriminant validity demonstrating the different constructs evaluated $\left[+X^{2}(3)=0,000, \mathrm{p}<.0001\right]$.

\subsection{Perceptions of the Acquiring and the Acquired Members}

Means, standard deviations, Cronbach alphas, and correlations about how the acquiring and acquired members perceive themselves and each other are presented in Table 4.

Table 4. Descriptive Data. Means, Standard Deviations, and Correlations

\begin{tabular}{|c|c|c|c|c|c|c|c|c|c|c|}
\hline Variable & Mean & S.D. & 1 & 2 & 3 & 4 & 5 & 6 & 7 & 8 \\
\hline 1. PICKER Organizational Identity & 4.55 & 0.76 & $(.97)$ & & & & & & & \\
\hline 2. APPLE Organizational Identity & 4.72 & 0.78 & a & $(.95)$ & & & & & & \\
\hline 3. PICKER Organizational Image & 4.33 & 0.90 & a & .22 & $(.95)$ & & & & & \\
\hline 4. APPLE Organizational Image & 3.47 & 0.97 & -.03 & a & a & $(.96)$ & & & & \\
\hline 5. PICKER CEI & 4.38 & 0.79 & $.49 * *$ & a & a & $.37 * *$ & $(.96)$ & & & \\
\hline 6. APPLE CEI & 4.59 & 0.67 & $\mathrm{a}$ & $.52 * *$ & $.37 *$ & a & $\mathrm{a}$ & $(.93)$ & & \\
\hline 7. PICKER Acquisition's Consequences & 4.17 & 0.63 & $.27^{* *}$ & a & a & $.40^{* *}$ & $.35^{* *}$ & a & $(.83)$ & \\
\hline 8. APPLE Acquisition's Consequences & 4.27 & 0.70 & $\mathrm{a}$ & .19 & $.54 * *$ & $\mathrm{a}$ & $\mathrm{a}$ & $.30 *$ & $\mathrm{a}$ & $(.85)$ \\
\hline
\end{tabular}

Note: Numbers in parentheses on the diagonal are the Chronbach's alpha coefficients of the scales. ${ }^{*} \mathrm{p}<.05 ;{ }^{* *} \mathrm{p}<.01$. a It was not possible to compute the correlation between these variables, because the respondents are not the same. For each variable (identity, image, CEI and acquisition's consequences) a total of 195 responses were obtained and then categorized into responses from PICKER and responses from APPLE.

PICKER $(\mathrm{M}=4.55)$ and APPLE members $(\mathrm{M}=4.72)$ present a positive identity. Organizational images of both companies were positive, but APPLE was perceived by members of the PICKER organization in a less positive light $(\mathrm{M}=3.47)$. Both companies perceived each others' evaluations in a positive way $\left(\mathrm{M}_{\mathrm{PICKER}}=4.38 ; \mathrm{M}_{\mathrm{APPLE}}=\right.$ 4.59). Regarding the evaluation of the acquisition, members from both companies perceived post-acquisition phase in a relatively positive way $\left(\mathrm{M}_{\mathrm{PICKER}}=4.17 ; \mathrm{M}_{\mathrm{APPLE}}=4.27\right)$. All scales had adequate Cronbach alphas, indicating high levels of reliability (between 0.83 and 0.97 ).

\subsubsection{Picker}

To study H1, which predicted that there would be consistency between organizational identity and organizational image during post-acquisition phase for members from the acquiring company, a T-Test for independent samples was used. Results showed that differences between the means of both groups were not significant [t (194) = 1.4; $\mathrm{p}>$.05]. The organizational identity $(\mathrm{M}=4.55)$ of PICKER did not differ significantly from its organizational image $(\mathrm{M}=4.33)$. There was consistency between how PICKER members perceived themselves and how they were perceived by APPLE members. This result was also supported by qualitative data, which revealed that PICKER members were perceived by both groups as having high market orientation and flexibility when dealing with customers. As one APPLE member described:

“They [PICKER members] try to sell the product that is most adapted to the customer's needs. If the customer says that the product is really expensive, they show flexibility to negotiate".

$\mathrm{H} 2$ proposed that in the case of members from the acquiring company, there would be consistency between organizational identity and CEI during post-acquisition phase. The T-Test for paired samples demonstrated significant differences between organizational identity and CEI [(t $(194)=3.3 ; \mathrm{p}<.01]$. For PICKERs, the organizational identity $(M=4.55)$ was significantly different from CEI $(M=4.38)$. The organizational identity shared by the PICKER members was significantly more positive than the way they expected to be perceived by APPLE members. This result is also in accordance with the qualitative data, as can be seen by the following passage from one PICKER member:

"They [APPLE members] think that we [PICKER members] do not care about problems and that the majority of us do not even talk to them.” 


\subsubsection{Apple}

Hypothesis 3 proposed that, concerning members from the acquired company, organizational identity would be perceived as more positive than organizational image during the post-acquisition phase. The T-Test for independent samples showed the presence of significant differences between the means of both groups [t $(194)=$ 6.4; $\mathrm{p}<.01$ ]. For APPLE, organizational identity $(\mathrm{M}=4.72)$ was significantly more positive than organizational image $(M=3.47)$. Members from the acquired company perceived themselves in a more positive light than they were perceived by the acquiring members, as mentioned by one PICKER member:

"They [APPLE members] need to develop their selling skills. They have to be more flexible when negotiating with customers if they really want to sell."

To test H4, which predicted that organizational identity would be perceived as more positive than CEI for members from the acquired company during the post-acquisition phase, we used a T-Test for paired samples. Results showed the existence of significant differences between both perceptions [ $t(194)=2.4$; $p<.05]$. Once more, for APPLE organizational identity was significantly different from its CEI [t (194) $=2.4$; $\mathrm{p}<.05$ ]. Organizational identity was significantly more positive $(M=4.72)$ than CEI $(M=4.59)$. The acquired members perceived themselves in a more positive fashion than they thought they were perceived by members of the acquiring company, as pointed out by one APPLE member:

"I do believe that they [PICKER members] do not like us very much. They think that they are better than us, especially in selling."

\subsubsection{Relations among Identity, Image and CEI in the Post-acquisition Phase}

To analyze H5, which proposed that identity, image and CEI altogether have a more significant impact on the evaluation of intergroup relations that any of them independently, we first conducted an exploratory factor analysis on the items to assess the dimensionality of the consequences of the acquisition. Six factors emerged and were named: personal challenge, success of the acquisition, organizational effectiveness, career benefits, intergroup relations and growth of the company (Table 5).

Table 5. Exploratory Factor Analysis on the Items of the “Acquisition's Consequences”

\begin{tabular}{|c|c|c|c|c|c|c|}
\hline \multirow[b]{2}{*}{ Item } & \multicolumn{6}{|c|}{ Factors } \\
\hline & $\begin{array}{l}\text { Personal } \\
\text { Challenge }\end{array}$ & $\begin{array}{l}\text { Success of the } \\
\text { Acquisition }\end{array}$ & $\begin{array}{l}\text { Organizational } \\
\text { Effectiveness }\end{array}$ & $\begin{array}{l}\text { Career } \\
\text { Benefits }\end{array}$ & $\begin{array}{l}\text { Intergroup } \\
\text { Relations }\end{array}$ & $\begin{array}{l}\text { Growth of the } \\
\text { Company }\end{array}$ \\
\hline 1 & .701 & & & & & \\
\hline 5 & .768 & & & & & \\
\hline 12 & .544 & & & & & \\
\hline 21 & .530 & & & & & \\
\hline 2 & & .590 & & & & \\
\hline 4 & & .640 & & & & \\
\hline 10 & & .520 & & & & \\
\hline 13 & & .774 & & & & \\
\hline 3 & & & .790 & & & \\
\hline 7 & & & .680 & & & \\
\hline 9 & & & .715 & & & \\
\hline 18 & & & .557 & & & \\
\hline 8 & & & & .679 & & \\
\hline 19 & & & & .637 & & \\
\hline 22 & & & & .690 & & \\
\hline 23 & & & & .582 & & \\
\hline 15 & & & & & .656 & \\
\hline 17 & & & & & .700 & \\
\hline 20 & & & & & .724 & \\
\hline 6 & & & & & & .550 \\
\hline 11 & & & & & & .561 \\
\hline 14 & & & & & & .590 \\
\hline 16 & & & & & & .656 \\
\hline
\end{tabular}


The evaluation of intergroup relations, composed by the items 15, 17 and 20, was used as the dependent variable. We used both regression analysis and structure equation modeling (SEM), the latter because it is a powerful way of testing regression equations between multiple latent independent and dependent variables, each one measured by multiple indicators, simultaneously (Hair, Anderson, Tatham \& Black, 1998).

Table 6. Results of Regression Analysis (RA) and Structural Equation Modeling (SEM): Effects of Antecedents on Acquisition's Consequences

\begin{tabular}{|c|c|c|c|c|c|c|c|c|}
\hline \multirow{2}{*}{ Variable } & \multicolumn{2}{|c|}{ Model 1} & \multicolumn{2}{|c|}{ Model 2} & \multicolumn{2}{|c|}{ Model 3} & \multicolumn{2}{|c|}{ Model 4} \\
\hline & RA & SEM & RA & SEM & RA & SEM & RA & SEM \\
\hline Organizational Identity & $.05^{* *}$ & $.06^{* * *}$ & & & & & $.04 *$ & $.04 *$ \\
\hline Organizational Image & & & $.15^{* *}$ & $.45^{* * *}$ & & & $.08 * *$ & $.30 * *$ \\
\hline CEI & & & & & $.20 * *$ & $.52 * * *$ & $.12^{* *}$ & $.35^{* * *}$ \\
\hline Normed Chi-square $\left(X^{2} / d f\right)$ & & $1.98 * *$ & & $1.84^{* *}$ & & $1.78^{* *}$ & & $1.75^{* *}$ \\
\hline
\end{tabular}

Note: ${ }^{*} \mathrm{p}<.05 ; * * \mathrm{p}<.01 ; * * * \mathrm{p}<.001$.

Table 6 reports the results of regression analysis as well as SEM. In order to test the impact on the evaluation of intergroup relations, we entered first with organizational identity (model 1). Then, we compared this model with alternative ones. In model 2 we considered only organizational image as the independent variable and in model 3 only CEI was measured. In the last step, we entered with identity, image and CEI at the same time. Results showed that CEI was a better antecedent of the evaluation of intergroup relations than both organizational identity $\left[+X^{2}(1)=214,336 \mathrm{p}<.001\right]$ and organizational image $\left[+X^{2}(1)=79,855 \mathrm{p}<.001\right]$. The model considering CEI, identity and image as antecedents of the evaluation of intergroup relations at the same time provided a better fit to the data $\left[+X^{2}(3473)=5879,104 \mathrm{p}<.001\right]$ than did the other models. All the fit indexes of this model were moderately better than those of the other models $\left[X^{i 2} / d f=1.75\right.$, goodness-of-fit index (GFI) $=.92$, comparative fit index $(\mathrm{CFI})=.80$, root-mean-square error of approximation $(\mathrm{RMSEA})=.06]$.

Below, we can find table 7 that outlines all our results.

Table 7. Summary of our results

\begin{tabular}{lll}
\hline & Picker - The Acquiring Company & Apple - The Acquired Company \\
\hline $\begin{array}{l}\text { Identity - Image } \\
\text { Identity - CEI }\end{array}$ & $\begin{array}{l}\text { The Identity is consistent with the Image. } \\
\text { The Identity is more positive than CEI. }\end{array}$ & $\begin{array}{l}\text { The Identity is more positive than Image. } \\
\text { The Identity is more positive than CEI. }\end{array}$ \\
\hline $\begin{array}{l}\text { Identity, Image } \\
\text { and CEI }\end{array}$ & $\begin{array}{l}\text { Identity, Image and CEI altogether have a more significant impact on intergroup relations that any of } \\
\text { them alone. }\end{array}$ \\
\hline
\end{tabular}

\section{Discussion and Conclusions}

The purpose of our study was to test the effect of the relationship among the identity, image and construed external image of both the acquiring and the acquired companies on intergroup relations, during the post-acquisition phase. Considering that the literature on mergers and acquisitions has focused mainly on the differences between group identities, we proposed that image and CEI would also be important for understanding how different organizational members perceive interactions with each other. We studied the PICKER and APPLE framework to suggest that the identity, image and CEI altogether would contribute to better evaluation of intergroup behavior in the new post-acquisition company and, potentially, in other post-acquisition companies.

We have empirically verified that the organizational identity of the acquiring company was consistent with its organizational image (Hypothesis 1). In other words, members from the acquiring company were perceived by others (people from the acquired company) the same way that they saw themselves. Our results demonstrated that during post-acquisition, members from PICKER behaved in a way that was congruent with their identity, revealing that these individuals perceived the acquired company the same way as their own company (Risberg, 1999). A sense of continuity was perceived between the old and the new organization (Knippenberg et al., 2002), which may indicate that the organizational identity of the post-acquisition company was similar to that of the acquiring organization, which is the dominant company.

This result provides evidence for the conclusions of Rosson and Brooks (2004), which states that the identity of the acquiring company tends to be maintained in the post-acquisition identity. After the acquisition, differences in group status were recognized by both PICKER and APPLE (Terry \& Callan, 1998; Terry \& O’Brien, 2001), 
and so, members from PICKER were regarded by members from APPLE as the high-status group, in congruence with their own self-views.

Contrary to our assumption, we have found no consistency between identity and CEI of members from the acquiring company (Hypothesis 2). Members from PICKER expected to be evaluated in a more negative way than they perceived themselves. Even recognizing that they were the high-status group (Risberg, 1999), members from PICKER did not expect their counterparts to evaluate them in a way consistent with their identity. This discrepancy between identity and CEI can be explained by taking into account the evaluation of the acquisition. In fact, there were no differences between how members of the two companies perceived the acquisition $\left[\mathrm{M}_{\text {PICKER }}=4.17, \mathrm{M}_{\text {APPLE }}=4.27 ; \mathrm{t}(194)=0.7 ; \mathrm{p}>.05\right]$. This result differs from other studies (e.g., Terry \& Callan, 1998) in which members from the acquired company perceived the acquisition process in a more threatening way than the acquiring members.

We further analyzed how both groups responded to items specifically concerned with the intergroup relations (analysis of items 15, 17 and 20 of the scale "Evaluation of the Acquisition" - Table 2). We computed the means of the responses of each group to each of these items, and found no significant differences [item 15: M $(P I C K E R)=3.18 \& \mathrm{M}($ APPLE $)=2.96, \mathrm{t}(194)=0.8 ; \mathrm{p}>.05$; item 17: $\mathrm{M}($ PICKER $)=2.74 \& \mathrm{M}($ APPLE $)=$ 2.95, t $(194)=0.7 ; \mathrm{p}>.05$; item 20: $\mathrm{M}($ PICKER $)=3.43 \& \mathrm{M}($ APPLE $)=3.51$, t $(194)=1.3 ; \mathrm{p}>$.05]. Even perceiving the acquisition situation in a relatively positive fashion, members from PICKER and those from APPLE did not evaluate relationships with their counterparts in a positive way, which means both groups were feeling apprehensive about each other. Because members from PICKER did not feel at ease when dealing with their colleagues, they were unable to reduce or avoid cognitive dissonance either to maintain perceptions of predictability or control (Swann, Stein-Seroussi \& Giesler, 1992).These feelings may explain why they were expecting to be evaluated in a more negative way by their counterparts.

Our case study also revealed that the identity of members from the acquired company was perceived as more positive than their organizational image (Hypothesis 3). This means that members from APPLE defined themselves in a more positive way than the way they were perceived by members from PICKER. When their relative low-status becomes salient, meaning that their identity was being threatened, they acted in order to restore positiveness (Elsbach \& Kramer, 1996; Turner \& Tajfel, 1979). They displayed high levels of ingroup bias to achieve a positive identity (e.g. Terry \& Callan, 1998; Terry \& O'Brien, 2001). This attempt to restore positiveness explains why members from APPLE shared a positive identity $(M=4.72)$. Although trying to develop a more positive identity, both groups acknowledged their differences in status. Members from PICKER formed a more negative impression of those of APPLE, and the organizational image of the members from $A P P L E$ was perceived in a more negative way than their organizational identity.

Our study also demonstrated that the organizational identity of members from APPLE was perceived as more positive than their CEI (Hypothesis 4). This means that members from this organization perceived themselves in a more positive way than the way they thought they were perceived by members from PICKER. This may be explained by the status-differences between groups. Because members from both companies perceived status differences (Terry \& Callan, 1998; Terry \& O’Brien, 2001), the low-status group expected to be evaluated in a somewhat negative light by the high-status group.

Finally, our case study also revealed that identity, image and CEI altogether had a more significant impact on how different organizational members evaluated intergroup relations than each of these variables when isolated (Hypothesis 5). Moreover, results revealed that intergroup relations were not perceived in a positive way, which mean that both members from PICKER and APPLE did not recognize ease during the integration in the post-acquisition firm. The identity, image and CEI altogether may explain why members from both the acquiring and acquired companies felt apprehensive about each other. Given that consistency between identity and CEI was obtained neither for PICKER nor for APPLE, on the one hand, and that CEI had a more significant impact on the evaluation of intergroup relations than did either identity or image, on the other hand, we may assert that members from both PICKER and APPLE felt apprehensive in the post-acquisition firm because they thought their colleagues perceived them in a more negative way. As CEI was not consistent with identity, individuals did not enhance perceptions of either predictability or control in relation to each other (Swann et al., 1992), which derailed high-quality and trust-based relations between them. Several authors have demonstrated how identity, image and CEI, alone, are important to explain intergroup behaviors (e.g. Terry \& Callan, 1998; Swan, 1987; Gioia, Shultz \& Corley, 2000). This case study advanced these lines of research by showing that the relationship among these perceptions is more important to understand post-acquisition integration, than these variables in isolation. The dynamic of this relationship should thus be taken into account in order to improve the performance of both groups and the organization. 


\subsection{Implications for Teams and Groups Processes Literature}

By examining identity, image and CEI of both the acquiring and acquired companies, our case study evidenced that the relationship among these three vectors might well contribute to a better understanding of intergroup integration in the post-acquisition company. Given this, we can draw important implications for the group dynamics as well as for organizational literature. As we have found consistency neither between the identity and image of the acquired members nor between the identity and CEI of both groups, our study revealed that intergroup perceptions following an acquisition might not be similar. In other words, the acquiring and the acquired members may not share the same views about themselves and about each other. As demonstrated, these inconsistencies tend to affect how the acquiring and the acquired members perceive intergroup relationships, explaining why both groups were feeling apprehensive about interacting and cooperating with each other. Given that members from the acquiring and the acquired companies did not cooperate, serious hurdles to the development of a common identity are created, as cooperation is a crucial condition for the identity construction (Tajfel, 1982; Ybema et al., 2009).

In addition to differences in organizational identity or intergroup status, as evidenced by other researchers (Terry \& Callan, 1998; Terry \& O’Brien, 2001), our study highlighted that both image and CEI occupy a very important role in the interpretation of interactions between different groups following an acquisition. Even more important than taking into account these variables per se, our study demonstrated that intergroup behavior after an acquisition can be best understood when considering the identity, image and CEI triangle. Specifically, consistency between identity and image as well as identity and CEI seems to promote better evaluations of interaction and cooperation between the acquiring and the acquired members, contributing to better post-acquisition integration. This same conclusion supports what some researchers have been defending, that the success of acquisitions rests on how the acquiring and the acquired companies are similar and complementary to each other (Finkelstein \& Haleblian, 2002), which are responsible for interaction and coordination during the post-acquisition phase (Larson \& Finkelstein, 1999; Graebner \& Eisenhardt, 2004). Based on our case study, we may thus conclude that the success of organizational change in general, and mergers and acquisitions in particular, is in part dependent on the consistency between identity and image, and identity and CEI.

Furthermore, our study suggests that CEI is even more important in explaining how intergroup relations are evaluated between the acquiring and the acquired companies than are either identity or image. Even recognizing the importance of minimizing discrepancies between identity and CEI (Dutton \& Dukerich, 1991; Gioia et al., 2000; Gioia \& Thomas, 1996), this relationship was to be examined empirically. We tested it and found consistency between identity and CEI in neither the high-status company nor the low-status company. By evidencing these results, our study highlights the value of the relationship between identity and CEI, showing that the identity-image relationship is a limited way of addressing the study of intergroup behavior. This builds on the literature on organizational change and intergroup processes, which has focused mainly on organizational identity and image as well as on the relationship between them (Larsson et al., 2003; Milton \& Westphal, 2005).

Our study also clarified the difference between image and CEI as two distinct concepts. As discussed, organizational image and CEI has often been treated as synonyms (Dutton \& Dukerich, 1991; Hatch \& Schultz, 1997). Our study demonstrated that they are distinct concepts, with independent and sometimes differential relationships with identity.

In summary, the study of the identity, image and CEI triangle may lead to a better understanding of intergroup relations following an acquisition. Consistency among identity, image and CEI may promote interaction, trust and cooperation between members from different companies, thus contributing to more positive dynamics following organizational change. We have thus contributed with a small step toward a more nuanced understanding of why organizational change in general, and acquisitions in particular, fail or succeed.

\subsection{Implications for Practioners}

Given the importance of the consistency among identity, image and CEI during mergers and acquisitions, important practical implications can be derived. In order to contribute to a better intergroup relationship during post-acquisition phase, leaders and managers should strive to identify the identity, image and CEI of both groups after an acquisition. Similar to the workshops advocated by Mirvis and Marks (1992), emphasizing the characteristics of the business as well as the beliefs and values beyond each group, we suggest that workshops focusing on how members perceive themselves and each other may help to change these same perceptions. As pointed out by scholars of organizational change (e.g. Nadler, 1988), after becoming aware of the differences, individuals are more prone to change their perceptions with the purpose of diminishing conflicts and enhancing intergroup interaction and cooperation, thus facilitating integration following organizational change. In this 
sense, this article may lead to the development of new instruments of organizational diagnosis based on perceptions of individuals from both groups about identity, image and CEI. On the other hand, the information about identity, image and CEI may be helpful to organizational development or change consultants to drive the change inherent to a acquisition process.

\subsection{Limitations of the Study and Future Directions}

Our study has some limitations that deserve consideration. Although single-case studies are primarily generalizable to theory (Miles \& Huberman, 1994; Yin, 1986), our conclusions were based on a single organization. The discrepancies we found between identity and CEI as well as identity and image require subsequent study with more diverse samples, in order to investigate the conditions that promote better merger and acquisition dynamics. Similarly, the impact of such inconsistency on the behavior of individuals must await further study.

Our research was conducted three months after the acquisition. Although our investigation has evidenced differences between the identities of the two companies, these could be even more pronounced if we had collected data before the acquisition. We suggest that future studies on mergers and acquisitions measure identity before and after these processes have transpired, as a way to understand how identity develops over time. Moreover, we based our study on a relatively small sample. APPLE was indeed quite a small company, with only 52 employees. More studies using large samples are needed to understand intergroup behavior following acquisitions.

Concerns about the measures used in the study should also be pointed out. To measure organizational image, we intentionally limited the answers of members from each company to their perceptions about members from the other company only, because we were interested in studying the relationships between both groups. However, image is defined by Alvesson (2001) and Berg (1985) as the way outsiders (all the relevant stakeholders) perceive the organization. Future studies might address this limitation, in order to get a more complete picture of outside perceptions of an organization.

\section{Acknowledgements}

We thank Albino Lopes, Miguel Pina e Cunha and Jean Bartunek for their suggestions and comments.

\section{References}

Albert, S. (1998). The Definition and Metadefinition of Identity. In Whetten, D. and P. Godfrey (Eds.), Identity in Organizations: Developing Theory through Conversation. Thousand Oaks, CA: Sage. http://dx.doi.org/10.4135/9781452231495.n1

Albert, S., \& Whetten, D. (1985). Organizational Identity. In L. L. Cummings and B. M. Staw (Eds.), Research in Organizational Behavior (vol. 7, pp. 263-295). Greenwich CT: JAI.

Alvesson, M., Ashcraft, K. L., \& Thomas, R. (2008). Identity matters: Reflections on the construction of identity scholarship in organization studies. Organization, 15, 5-28. http://dx.doi.org/10.1177/1350508407084426

Andrade, G., Mitchell, M., \& Stafford, E. (2001). New Evidence and Perspectives on Mergers. Journal of Economic Perspectives, 15(2), 103-120. http://dx.doi.org/10.1257/jep.15.2.103

Ashforth, B., \& Mael, F. (1989). Social Identity Theory and the Organization. Academy of Management Review, 14(1), 20-39. http://dx.doi.org/10.5465/AMR.1989.4278999

Auster, E., \& Sirower, M. (2002). The Dynamics of Merger and Acquisition Waves: A Three Stage Conceptual Framework. Journal of Applied Behavioral Science, 38(2), 216-244. http://dx.doi.org/10.1177/00286302038002005

Bartel, C. (2001). Social Comparison in Boundary-Spanning Work: Effects of Community Outreach on Members' Organizational Identity and Identification. Administrative Science Quarterly, 46(3), 379-413. http://dx.doi.org/10.2307/3094869

Berg, P. (1985). Organization Change as a symbolic Transformation process. In P. Frost, Moore, M. Louis, C. Lundberg and J. Martin (Eds.), Reframing Organizational Culture (pp. 281-300). CA: Sage.

Cornett-DeVito, M., \& Friedman, P. (1995). Communication processes and merger success: An exploratory study of four financial institution mergers. Management Communication Quarterly, 9(1), 46-77. http://dx.doi.org/10.1177/0893318995009001003

Creswell, J. (2003). Research design: Qualitative, quantitative, and mixed methods approaches (2nd ed.). Thousand Oaks, CA: Sage. 
Desrochers, S., \& Sargent, J. (2004). Identity Theory. Organization Management Journal, 1, 61-69. http://dx.doi.org/10.1057/omj.2004.14

Dutton, J., \& Dukerich, J. (1991). Keeping an Eye on the Mirror: Image and Identity in Organizational Adaptation. Academy of Management Journal, 34(3), 517-554. http://dx.doi.org/10.2307/256405

Dutton, J., Dukerich, J., \& Harquail, C. (1994). Organizational Images and Member Identification. Administrative Science Quarterly, 39(2), 239-263. http://dx.doi.org/10.2307/2393235

Elsbach, K., \& Kramer, R. (1996). Members'response to organizational identity threats: Encountering and countering the business week rankings. Administrative Science Quarterly, 41(3), 442-482. http://dx.doi.org/10.2307/2393938

Empson, L. (2004). Organizational identity change: managerial regulation and member identification in an accounting firm acquisition. Accounting, Organizations and Society, 29(8), 759-781. http://dx.doi.org/10.1016/j.aos.2004.04.002

Festinger, L. (1957). A theory of cognitive dissonance. Stanford, CA: Stanford University Press.

Finkelstein, S., \& Haleblian, J. (2002). Understanding Acquisition Performance: The Role of Transfer Effects. Organization Science, 13(1), 36-47. http://dx.doi.org/10.1287/orsc.13.1.36.539

Fiol, C. M. (2002). Capitalizing on paradox: The role of language in transforming organizational identities. Organization Science, 13(6), 653-666. http://dx.doi.org/10.1287/orsc.13.6.653.502

Foreman, P., \& Whetten, D. (2002). Member's Identification with Multiple-Identity Organizations. Organization Science, 13(6), 618-635. http://dx.doi.org/10.1287/orsc.13.6.618.493

Gaughan, P. (2001). Mergers and Acquisitions: An Overview. In P. A. Gaughan (Ed.). Mergers, Acquisitions, and Corporate Restructurings (3rd ed.). New York: John Wiley \& Sons.

Gioia, D., \& Thomas, J. (1996). Identity, Image and Issue Interpretation: Sensemaking during Strategic Change in academia. Administrative Science Quarterly, 41(3), 370-407. http://dx.doi.org/10.2307/2393936

Gioia, D., Schultz, M., \& Corley, K. (2000). Organizational Identity, Image and Adaptative Instability. Academy of Management Review, 25(1), 63-81. http://dx.doi.org/10.2307/259263

Glick, W. (1985). Conceptualizing and Measuring Organizational and Psychological Climate: Pitfalls in Multilevel Research. Academy of Management Review, 10(3), 601-616. http://dx.doi.org/10.2307/258140

Graebner, M., \& Eisenhardt, K. (2004). The Seller's Side of the Story: Acquisition as Courtship and Governance as Syndicate in Entrepreneurial Firms. Administrative Science Quarterly, 49, 366-403.

Hatch, M. J., \& Schultz, M. (1997). Relations between Organizational Culture, Identity and Image. European Journal of Marketing, 31(5/6), 356-365. http://dx.doi.org/10.1108/eb060636

Hatch, M. J., \& Schultz, M. (2002). The Dynamics of Organizational Identity. Human Relations, 55(8), 989-1018. http://dx.doi.org/10.1177/0018726702055008181

Haunschild, P., Moreland, R., \& Murrell, A. (1994). Sources of resistance to mergers between groups. Journal of Applied Social Psychology, 24, 1150-1178. http://dx.doi.org/10.1111/j.1559-1816.1994.tb01549.x

Hogg, M., \& Terry, D. (2000). Social Identity and Self-Categorization Process in Organizational Contexts. Academy of Management Review, 25(1), 121-140. http://dx.doi.org/10.5465/AMR.2000.2791606

James, L., Demaree, R., \& Wolf, G. (1984). Estimating withingroup interrater reliability with and without response bias. Journal of Applied Psychology, 69, 85-98. http://dx.doi.org/10.1037/0021-9010.69.1.85

Knippenberg, D., Knippenberg, B., Monden, L., \& Lima, F. (2002). Organizational identification after a merger: A social identity perspective. British Journal of Social Psychology, 41, 233-252. http://dx.doi.org/10.1348/014466602760060228

Labianca, G., Fairbank, J., Thomas, J., Gioia, D., \& Umphress, E. (2001). Emulation in academia: Balancing structure and identity. Organization Science, 12(3), 312-330. http://dx.doi.org/10.1287/orsc.12.3.312.10101

Larson, R., \& Finkelstein, S. (1999). Integrating Strategic, Organizational and Human Resource Perspectives on Mergers and Acquisitions: A case study of synergy realization. Organization Science, 10(1), 1-26. http://dx.doi.org/10.1287/orsc.10.1.1 
Larsson, R., Brousseau, K., Driver, M., Holmqvist, M., \& Tarnovskaya, V. (2003). International growth through cooperation: Brand-driven strategies, leadership, and career development in Sweden. Academy of Management Executive, 17(1), 7-24. http://dx.doi.org/10.5465/AME.2003.9474807

Liao, H., \& Chuang, A. (2004). A Multilevel Investigation of Factors Influencing Employee Service Performance and Costumer Outcomes. Academy of Management Journal, 47(1), 41-58. http://dx.doi.org/10.2307/20159559

Mael, F., \& Ashforth, B. (1992). Alumni and their Alma Mater: A partial test of the reformulated model of organizational identification. Journal of Organizational Behaviour, 13, 103-123. http://dx.doi.org/10.1002/job.4030130202

Melawar, T., Hussey, G., \& Srivoravilai, N. (2005). Corporate visual identity: The re-branding of France Télécom. Brand Management, 12(5), 379-394. http://dx.doi.org/10.5465/AMJ.2005.16928393

Milton, L., \& Wesphal, J. (2005). Identity Confirmation Networks and Cooperation in Work Groups. Academy of Management Journal, 48(2), 191-212.

Parker, M. (2000). Organizational Culture and Identity. Sage: London.

Pratt, M., \& Rafaeli, A. (1997). Organizational Dress as a Symbol of Multilayered Social Identities. Academy of Management Journal, 40(4), 862-898. http://dx.doi.org/10.2307/256951

Rao, H., Davis, G., \&Ward, A. (2000). Embeddedness, Social Identity and Mobility: Why Firms leave the NASDAQ and join the New York Stock Exchange. Administrative Science Quarterly, 45(2), 268-292. http://dx.doi.org/10.2307/2667072

Rentsch, J., \& Schneider, B. (1991). Expectations for postcombination organizational life: A study of responses to merger and acquisition scenarios. Journal of Applied Social Psychology, 21, 233-252. http://dx.doi.org/10.1111/j.1559-1816.1991.tb02725.x

Rindova, V., \& Schultz, M. (1998). Identity within and without: Lessons from corporate and organizational identity. In Whetten, D. and Godfrey, P. (Eds.), Identity in Organizations: Developing Theory through Conversation. Thousand Oaks, CA: Sage.

Risberg, A. (1999). Ambiguities Thereafter - An interpretative approach to acquisitions. Malmö Sweden: Lind University Press.

Rosson, P., \& Brooks, M. (2004). M\&As and corporate visual identity: An exploratory study. Corporate Reputation Review, 7(2), 181-194. http://dx.doi.org/10.1057/palgrave.crr.1540219

Salk, J., \& Shenkar, O. (2001). Social Identities in an International Joint Venture: An Exploratory Case Study. Organization Science, 12(2), 161-178. http://dx.doi.org/10.1287/orsc.12.2.161.10111

Schneider, B., White, S., \& Paul, M. (1998). Linking service climate and costumer perceptions of service quality: Test of a causal model. Journal of Applied Psychology, 83, 150-163. http://dx.doi.org/10.1037/0021-9010.83.2.150

Schweiger, D., \& Weber, Y. (1989). Strategies for managing human resources during mergers and acquisitions: An empirical investigation. Human Resources Planning, 12, 69-86.

Seo, M., \& Hill, N. (2005). Understanding the human side of merger and acquisition: An integrative framework. Journal of Applied Behavioral Science, 41(4), 422-443. http://dx.doi.org/10.1177/0021886305281902

Stahl, G., \& Sitkin, S. (2002). Trust in Corporate Acquisitions. Working Paper 2002/61/ABA, INSEAD, R\&D.

Strauss, A., \& Corbin, J. (1998). Basics of Qualitative ReseaZebrah: Techniques and Procedures for Developing Grounded Theory (2nd ed.). Thousand Oaks, CA: Sage.

Swann, W. (1987). Identity negotiation: Where two roads meet. Journal of Personality and Social Psychology, 53, 1038-1051. http://dx.doi.org/10.1037/0022-3514.53.6.1038

Swann, W., Hixon, J., Stein-Seroussi, A., \& Gilbert, D. (1990). The fleeting gleam of praise: Behavioral reactions to self-relevant feedback. Journal of Personality and Social Psychology, 43, 59-66. http://dx.doi.org/10.1037/0022-3514.43.1.59

Swann, W., Pelham, B., \& Krull, D. (1989). Agreeable fancy or disagreeable truth? How people reconcile their self-enhancement and self-verification needs. Journal of Personality and Social Psychology, 57, 782-791. http://dx.doi.org/10.1037/0022-3514.57.5.782 
Swann, W., Stein-Seroussi, A., \& Giesler, R. (1992). Why People Self-Verify. Journal of Personality and Social Psychology, 62, 392-401. http://dx.doi.org/10.1037/0022-3514.62.3.392

Tajfel, H. (1982). Social Psychology of Intergroup Relations. Annual Review of Psychology, 33, 1-39. http://dx.doi.org/10.1146/annurev.ps.33.020182.000245

Tajfel, H., \& Turner, J. (1979). An Integrative Theory of Intergroup Conflict. In W. Austin and S. Worshel (Eds.), The Social Psychology of Intergroup Relations. Monterey: Brooks/ Cole.

Tajfel, H., \& Turner, J. (1986). The social identity theory of inter-group behavior. In S. Worchel and L. W. Austin (Eds.), Psychology of Intergroup Relations. Chicago: Nelson-Hall

Terry, D., \& Callan, V. (1998). Ingroup bias in response to an organizational merger. Group Dynamics: Theory, Research and Practice, 2(2), 67-81. http://dx.doi.org/10.1037/1089-2699.2.2.67

Terry, D., \& O’Brien, A. (2001). Status, legitimacy, and ingroup bias in the context of an organizational merger. Group Processes \& Intergroup Relations, 4(3), 271-289. http://dx.doi.org/10.1177/1368430201004003007

Vaara, E., Tienari, J., \& Säntti, R. (2003). The international match: Metaphors as vehicles of social identity-building in cross-border mergers. Human Relations, 56(4), 419-451. http://dx.doi.org/10.1177/0018726703056004002

Ybema, S., Keenoy, T., Oswick, C., Beverungen, A., Ellis, N., \& Sabelis, I. (2009). Articulating identities. Human Relations, 62(3), 299-322. http://dx.doi.org/10.1177/0018726708101904

Yin, R. (1986). Case Study Research: Design and Methods. California: Sage. 